\title{
Do we recognize obesity as an important hemodynamic, morpho- logic and cardiometabolic factor in echocardiographic evaluation?
}

\author{
(D) Kristina Selthofer- \\ Relatići,2* \\ 'University Hospital Centre \\ Osijek, Osijek, Croatia \\ 2University Josip Juraj \\ Strossmayer Osijek, Faculty \\ of Medicine, Osijek, Croatia
}

KEYWORDS: echocardiography, epicardial adipose tissue, left ventricle remodeling, obesity, right ventricle remodeling.

CITATION: Cardiol Croat. 2019;14(3-4):70. | https://doi.org/10.15836/ccar2019.70

*ADDRESS FOR CORRESPONDENCE: Kristina Selthofer-Relatić, Klinički bolnički centar Osijek, J. Huttlera 4, HR31000 0sijek, Croatia. / Phone: +385-31-511-717 / E-mail: selthofer.relatic@gmail.com

ORCID: Kristina Selthofer-Relatić, https://orcid.org/0000-0002-9890-6489

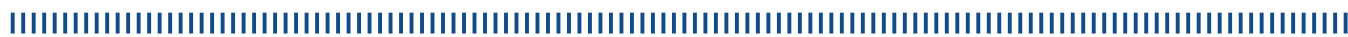

Obesity has become a global public health issue. Cardiac adaptation to obesity includes structural and functional changes of the heart. Anatomic and biomolecular characteristics of adipose tissue present it as an endocrine organ with neurohumoral adipokines activity. However, fat tissue differs according to embryologic origin, anatomic localization, gender and biomolecular properties. Qualitative and quantitative echocardiographic evaluation in obese patients can be crucial for detecting cardiometabolic risk factors.

Increased adipose mass causes functional and morphological changes of the heart. Increased body fat and body surface area are associated with increased blood volume, ventricle preload, resting output and stroke volume; supranormal systolic function and possible aortic root dilatation; abnormal left and right ventricle geometry, as a result of compensatory wall hypertrophy regarding pressure or volume overload; enlarged left and right ventricular end-diastolic diameter and elevated end-diastolic volume; and increased left atrium area and volume. Using indexed parameters in echo analysis in obese patients are recommended.

Early detection of obesity related cardiovascular abnormalities may be useful in the future for patient management. Particularly, strain echo acts as a technique for the early detection of subclinical changes of the left ventricle in obese patients, while epicardial adipose tissue is the newest echo detector of cardiac visceral fat as a cardiometabolic and right ventricle remodeling risk factor

Routine clinical echo practice in obese patients can be limited by technical factors, especially right heart morphologic and functional measurements. However, contrast and transesophageal echocardiography offers additional methods for cardiac structure visualization. ${ }^{1-4}$
RECEIVED:

February 28, 2019

ACCEPTED:

March 24, 2019

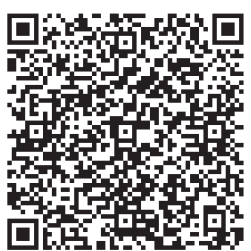

$\square$ Cardiologia Croatica 2019:14(3-4):70
10. hrvatski dvogodišnji ehokardiografski kongres s međunarodnim sudjelovanjem $10^{\text {th }}$ Croatian Biennial Echocardiography Congress with International Participation Poreč, 16. do 18.5.2019. 